\title{
Methodological bias in the estimations of important meroplanktonic components from near-shore bottoms
}

\author{
Simone Mariani ${ }^{1, *}$, María Jesús Uriz ${ }^{1}$, Xavier Turon ${ }^{2}$ \\ ${ }^{1}$ Centre d'Estudis Avançats de Blanes, C/ACC. Cala S. Francesc 14, 17300 Blanes (GI), Spain \\ ${ }^{2}$ Departament de Biologia Animal (Invertebrats), Facultat de Biologia, Universitat de Barcelona, Avgda. Diagonal 645, \\ 08028 Barcelona, Spain
}

\begin{abstract}
In spite of the many direct observations on larval release, the presence of lecithotrophic larvae of sponges and bryozoans has either been anecdotally or never reported in plankton studies. We collected plankton over an artificial rocky reef and on adjacent sandy bottoms in the NW Mediterranean and compared larval abundance and species richness of the major groups of invertebrates found over each of such substrates. Observations in the laboratory showed that formalin $(4 \%$ in seawater) irreversibly damaged most sponge larvae. To elude the effects of preservation and make it possible to culture larvae for later identification of juveniles, the samples were first identified in vivo and successively fixed. We compared larval abundance and species richness of the major groups of invertebrates found between samples observed in vivo and after preservation with formalin (a posteriori). The majority of the sponge larvae (93\%) were only visible in the samples observed in vivo whereas abundance estimations of bryozoan and ascidian larvae were equally achieved with both methods. Estimations of the species richness were biased after sample preservation for sponge and bryozoan larvae. We found significant differences between the numbers of planktotrophic larvae observed a posteriori and in vivo. Sponge larvae were the most abundant plankton collected over the reef where the adults live (38\% of the total larvae; maximum: 100 ind $\mathrm{m}^{-3}$ ) and among the most abundant over the sandy bottom (13\%). Bryozoan and ascidian larvae were scarce over both substrates $(<1 \%$ of the total) even though they were more abundant near parental habitats than on the sandy bottoms. Gastropod and mussel veligers and spionid larvae were the most abundant planktotrophic larvae. Early and late developmental stages of long-lived larvae such as those of barnacles and late stages of polychaetes and echinoderms were mostly collected over parental habitats (either the reef or sandy bottoms). From this report it appears that the importance of lecithotrophic larvae of sponges and bryozoans in near-shore meroplankton assemblages needs to be examined further.
\end{abstract}

KEY WORDS: Invertebrate larvae · Sponges · Bryozoans · Dispersal · Formalin preservation Resale or republication not permitted without written consent of the publisher

\section{INTRODUCTION}

Most data on the presence of benthic invertebrate larvae in near-shore plankton come from reports dealing with the structure and dynamics of zooplankton assemblages (e.g. Vives 1966, Valdes et al. 1990, Wang et al. 1994, Andreu \& Duarte 1996) and studies describing the horizontal distributions of larvae in coastal waters (e.g. Southward 1962, Mileikovsky 1968a,
Scheltema 1986). Near-shore plankton is most frequently sampled using plankton nets or other sampling devices (e.g. water pumps) handled from boats at a certain distance from the shore and shallow hard substrates. The larvae most often collected by such samplings are planktonic stages of molluscs, polychaetes, barnacles, decapods, and echinoderms (e.g. Mileikovsky 1968b, Sautor \& Castel 1995, Martin et al. 1997). Most species of these groups produce long- 
lived, wide-dispersing larvae (Jackson 1986), which are also common in off-shore waters (Scheltema 1971, Scheltema \& Williams 1983).

On the other hand, invertebrates such as sponges, most bryozoans and ascidians produce relatively small numbers of lecithotrophic larvae (Jackson 1985). Such larvae spend shorter periods in the plankton than planktotrophic larvae and often disperse over shorter distances (Lindquist \& Hay 1996). As a result, shortlived lecithotrophic larvae have been mainly collected by means of diver-towed plankton nets or other devices particularly designed for sampling in the close vicinity of parental habitats: mostly hard-substrate communities in temperate and tropical areas (Emery 1968, Sale et al. 1976, 1978, Palau et al. 1991). Ascidian tadpole larvae have been the lecithotrophic larvae most often collected by such samplings (Bingham 1992, Graham \& Sebens 1996). In contrast, despite the many direct observations on larval release from sponges and bryozoans in the literature (e.g. Ryland 1976, Amano 1988, Keough 1989, Hurlbut 1991, Linquist et al. 1997, Uriz et al. 1998), and with the exception of the anecdotal collection of sponge larvae made by Rützler et al. (1980), and the report of Trégouboff (1939) for the non-swimming, long-distance dispersing hoplitomella larva of Alectona, no plankton studies have ever mentioned the presence of sponge and coronate bryozoan larvae within the samples. The incongruity between direct observations of larval release and the results of plankton samplings conducted near habitats colonised by sponges and bryozoans deserves further investigation.

The present study is part of a research programme of which the main objective is to describe the structure and dynamics of meroplankton collected in a nearshore area characterised by hard and soft bottoms inhabited by rich assemblages of sessile benthic invertebrates (Mariani 2002). Here we aim to demonstrate that lecithotrophic larvae such as those of sponges and bryozoans may be important components of meroplankton from near-shore bottoms. We therefore collected plankton from adjacent hard and soft bottoms ca. twice a week over a period of $2 \mathrm{yr}$ and compared larval abundance and species richness of the major groups of invertebrates found over each of such substrates. By doing so, we attempted to show how larvae of near-shore bottom invertebrates distribute between different but adjacent habitats. Besides this, in the case of sponge and bryozoan larvae, we tested the importance of the distance from parental habitats (reef) at which they are collected to determine their abundance.

Prior to conducting this study, we had repeatedly observed that sponge larvae could be destroyed by the addition of formalin to the sample medium. We exam- ined the possibility that the widespread use of formalin to fix and preserve meroplankton may be responsible for the lack of sponge and lecithtohrophic bryozoan larvae in samples collected near parental habitats. To test this hypothesis and to allow larval cultures when necessary, all the samples were first processed in vivo and only subsequently preserved with formalin (4\% in seawater). By comparing larval abundance and species richness of the major groups of invertebrates, prior and after preservation, we attempted to show how each method of sample processing affected our estimations of the larvae in the samples.

\section{MATERIALS AND METHODS}

The study was carried out along the 65 yr old artificial reef that protects the Blanes Harbour (NW Mediterranean, Spain). This rocky reef has an average depth of $\sim 10 \mathrm{~m}$ and lies over a sandy bottom (see Mariani et al. 2000). The benthic communities on the reef are well developed. Sponges are the major group of sessile invertebrates, followed by the less abundant cheilostome bryozoans and ascidians (Mariani 2002). Conversely, polychaetes are the dominant invertebrates in the soft bottoms near the rocky shore (Pinedo 1998). At the study site the main hydrographic regime is a variable undertow perpendicular to the seaward harbour wall, and there are no currents moving in the same direction as the wall (Mariani et al. 2000, Mariani 2002).

Plankton was sampled once or twice a week between July 1998 and June 2000 at 11:00 h (total number of sampling days $=102$ ). This time of day was selected to allow the collection of lecithotrophic larvae such as those of sponges, bryozoans, and ascidians, which are mainly released during the morning daylight hours (Ryland 1976, Amano 1988, Svane \& Young 1989, Linquist et al. 1997). The high frequency and long period of sampling were chosen to cover shortand long-term (inter-annual) variability in larval abundance. A plankton net $22 \mathrm{~cm}$ in diameter and with $100 \mu \mathrm{m}$ mesh size was used. On each sampling day, the net was towed by a scuba diver $\sim 30 \mathrm{~cm}$ above the reef to ensure collection of short-dispersing larvae (e.g. sponge larvae, bryozoan coronate larvae, ascidian tadpoles, etc.) and on the soft bottoms in front of the reef ( $~ 5 \mathrm{~m}$ apart). Five sampling stations $\sim 30 \mathrm{~m}$ apart were selected on the reef at average depths of $\sim 8 \mathrm{~m}$, and 2 hauls were made at each station and sampling day, one on the reef and the other on the sandy bottoms. The water volume filtered at each haul was $\sim 1.36 \mathrm{~m}^{3}$. The hauls over the sandy bottom were made by zigzag swimming whilst towing the net as close as possible to the front of each station on the reef. The effective per- 
formance of this sampling method has been validated elsewhere (see Mariani et al. 2000).

The samples were transported to the laboratory immediately after collection. The contents of each sample were filtered through a $100 \mu \mathrm{m}$ mesh net and the samples obtained were kept in petri dishes with $100 \mu \mathrm{m}$ filtered seawater (FSW). The samples were first observed in vivo and all discernible larval forms belonging to invertebrate taxa were sorted and counted under a dissecting microscope (WILD M10).

Although many lecithotrophic larvae are distinguishable by their colours and behaviour, most of them were not identifiable to the species level under the dissecting microscope. In these cases clusters of larvae (from 5 to 20, depending on the availability) sharing similar external features were placed in separate petri dishes with FSW for settlement. After $\sim 2 \mathrm{wk}$, most larvae had settled and metamorphosed, and identification was done using morphologically specific characters of settlers. In the case of sponges, species identification was done by characterising distinctive spicules and/or spongin fibres under the light microscope. The planktonic stages of cnidarians collected were mostly anthozoan planulae, hydrozoan actinulae, hydromedusae, and scyphozoan ephyrae, although occasionally found, were extremely scant and are not dealt with in this study. Some larvae collected in the plankton sampling were identified by comparison with recently released larvae captured from the vicinity or the inside of brooding adults while scuba diving. Although we generally attempted to achieve identification to the lowest taxonomic level possible, identification was done before metamorphosis in the case of planktotrophic larvae; thus it was often achieved at the family or higher levels for the trochophore, mollusc, and polychaete larvae. Consequently, the species richness for those taxa may have been underestimated.

After in vivo identification and quantification $(\sim 4 \mathrm{~h}$ after collection), larvae (except those used for settlement) were returned to the respective samples. Buffered commercial formaldehide was added to each sample to a final concentration of $4 \%$. The preserved samples were sorted a posteriori 1 yr after collection. Species richness was estimated as the total number of taxa for each of the most numerous invertebrate groups found (see 'Results').

The effects of formalin were directly monitored in the laboratory on sponge larvae. We added 5 to 10 larvae of the taxa Ircinia oros, Dysidea avara, Pleraplysilla spinifera, Crambe crambe, Hymedesmia spp. to petri dishes containing buffered ( $4 \%$ in seawater) formalin. Changes in colour, size, and general morphology of larvae were recorded after $15 \mathrm{~min}, 6$ and $12 \mathrm{~h}$ under the dissecting microscope.

Statistical analysis was carried out using Wilcoxon's signed-ranks test (for paired variables) because the assumptions for parametric statistics could not be met. This analysis was used to test differences between the abundance of larvae and the numbers of taxa (species richness) counted in vivo versus those found a posteriori, and between the numbers of larvae (and species richness) found on the reef versus those on the sandy bottoms. Differences were analysed for each of the most numerous groups of invertebrates (see 'Results'). For the in vivo versus a posteriori comparisons, we had 1020 samples $(102$ sampling days $\times 2$ substrates $\times 5$ stations). For the reef versus sandy bottom comparisons we had 102 sampling days, 5 samples on the reef corresponding to the 5 stations $(\mathrm{n}=510)$ and 5 samples for the sandy bottoms $(\mathrm{n}=510)$. For the minor groups (see 'Results'), the low numbers of larvae did not allow statistical analysis.

\section{RESULTS}

The effects of formalin on the monitored sponge larvae varied depending on the time elapsed after fixation, the species, and the larva type. Right after the addition to the formalin medium, some larvae, Crambe crambe, broke up, possibly due to an osmotic change. After $15 \mathrm{~min}$, all the larvae observed showed shape alterations. In some species, colours started to fade (i.e. Ircinia oros and Dysidea avara) or were altered (i.e. from yellow to brown for larvae of the genus Hymedesmia), and the bodies of all the larvae wrinkled. More serious damage was observed after $6 \mathrm{~h}$ from fixation when larvae broke (all larvae of $I$. oros, $D$. avara, and Pleraplysilla spinifera). All the observed larvae of $P$. spinifera disintegrated in the sample medium at that time. In the following hours, disintegration could be easily provoked by gentle shaking of the petri dishes or simply by withdrawal with a pipette.

\section{In vivo versus a posteriori comparisons}

The abundance of sponge larvae and the number of taxa (see Table 1 for the species list) were significantly different depending on whether samples were observed in vivo or a posteriori (Fig. 1). Only a small proportion $(\sim 7 \%)$ of the larvae counted in vivo were visible again a posteriori (Fig. 1). The values of abundance and species richness presented in Fig. 1 were probably overestimated, because most of the larvae in the preserved samples were in such bad condition that only knowledge of their original features could help in recognising them as sponge larvae.

Both gastropod and mussel veligers were more easily counted a posteriori than in vivo and, at the identification level achieved in this study, virtually the same 
Table 1. List of taxa relative to the major groups of invertebrates found in samples

\begin{tabular}{|c|c|}
\hline Major group & Taxon \\
\hline Sponges & $\begin{array}{l}\text { Apysilla sulfurea (Schulze) var. rosea } \\
\text { Cacospongia mollior Schmidt } \\
\text { Chalinula limbata (Montagu) } \\
\text { Chalinula sp. } \\
\text { Chellonaplysilla noevus (Buscarte) } \\
\text { Cliona viridis (Schmidt) } \\
\text { Crambe crambe (Schmidt) } \\
\text { Dysidea avara (Schmidt) } \\
\text { Hymedesmia spp. } \\
\text { Haliclona sp. } \\
\text { Ircinia oros (Schmidt) } \\
\text { Mycale cf. macilenta } \\
\text { Mycale rotalis (Bowerbank) } \\
\text { Oscarella sp. } \\
\text { Phorbas tenacior (Topsent) } \\
\text { Pleraplysilla spinifera (Schulze) } \\
\text { Poecilosclerida spp. } \\
\text { Raphidophlus jolicoeuri Topsent } \\
\text { Scopalina lophyropoda (Schmidt) } \\
\text { Spongiidae sp. } \\
\text { Tedania anhelans (Lieberhühn) }\end{array}$ \\
\hline Gastropods & $\begin{array}{l}\text { Caecum sp. } \\
\text { Unidentified prosobranch no. } 1 \\
\text { Unidentified prosobranch no. } 2\end{array}$ \\
\hline Bivalves & $\begin{array}{l}\text { Unidentified bivalve no. } 1 \\
\text { Unidentified bivalve no. } 2 \\
\text { Unidentified bivalve no. } 3 \\
\text { Unidentified bivalve no. } 4 \\
\text { Unidentified bivalve no. } 5\end{array}$ \\
\hline Polychaetes & $\begin{array}{l}\text { cf. Boccardia } \\
\text { Magelona sp. } \\
\text { Owenia fusiformis (Delle Chiaie) } \\
\text { Pseudopolydora sp. } 1 \\
\text { Pseudopolydora sp. } 2 \\
\text { Unidentified Nereididae } \\
\text { Unidentified Phyllodocidae } \\
\text { Unidentified Polynoidae } \\
\text { Unidentified Sabellaridae } \\
\text { Unidentified Spionid } \\
\text { Unidentified trochophore larvae }\end{array}$ \\
\hline Crustaceans & $\begin{array}{l}\text { Acasta spongites (Poli) } \\
\text { Balanus amphitrite Darwin } \\
\text { Balanus perforatus Bruiguière } \\
\text { Elminius modestus Darwin } \\
\text { Verruca stroemia (Müller) }\end{array}$ \\
\hline Bryozoans & $\begin{array}{l}\text { Bugula sp. } \\
\text { Schizobrachiella sanguinea (Norman) } \\
\text { Unidentified cheilostome no. } 1 \\
\text { Unidentified cheilostome no. } 2 \\
\text { Unidentified cyphonautes larvae }\end{array}$ \\
\hline Echinoderms & $\begin{array}{l}\text { Echinocardium cordatum (Pennant) } \\
\text { Ophiothrix fragilis (Abilgard) } \\
\text { Paracentrotus lividus Lamark } \\
\text { Unidentified asteroid larvae } \\
\text { Unidentified holoturian larvae }\end{array}$ \\
\hline Ascidians & $\begin{array}{l}\text { Botryllus schlosseri (Pallas) } \\
\text { Diplosoma spongiforme (Giard) } \\
\text { Unidentified solitary species no. } 1 \\
\text { Unidentified solitary species no. } 2\end{array}$ \\
\hline
\end{tabular}

numbers of taxa (see Table 1) were detected in vivo and a posteriori (Fig. 1). Spionid larvae accounted for $76.6 \%$ of total polychaetes (see Table 1). Larvae of polychaetes were more accurately counted a posteriori than in vivo (Fig. 1). Although identification was easier in vivo because, once preserved, some larvae (spionids) had lost the distinctive dorsal and ventral pigmented dots, we did not find significant differences between the number of polychaete taxa discernible in vivo or a posteriori (Fig. 1).

Nauplii (Stage II) and cyprids were the most abundant larval stages of barnacles for all the species collected (see Table 1). Significantly higher numbers of barnacle larvae were counted a posteriori than in vivo (Fig. 1). However, both methods of sample treatment allowed accurate identification of species.

Quantification of bryozoan larvae was equally achievable in vivo and a posteriori, while significantly more bryozoan taxa were discernible in vivo (Fig. 1). This is taking into accout that, although they had lost their distinctive colours and were often damaged, we recognised the large Schizobrachiella sanguinea larvae both because of our previous knowledge of their features in vivo and because they were the only coronate bryozoan larvae of this size in the samples. However, smaller coronate larvae of other cheilostomes (see Table 1) were not discernible after preservation. The few cyphonautes were recognised in both the in vivo and a posteriori samples.

Significantly more echinoderm larvae (mainly ophioplutei) were discernible a posteriori, while the number of taxa (see Table 1) identified was similar for both treatments (Fig. 1).

Although the colours of some species were lost, ascidian tadpoles were not damaged by preservation, and both abundance estimations and taxon identifications were similarly achieved in vivo and a posteriori (Fig. 1).

Planulae of cnidarians, larvae of phoronids, sipunculans, nemertines, decapods, and Cephalochordata accounted together for $<1 \%$ of the total abundance of larvae. Among these minor groups, we found the planulae of the solitary scleractinian Caryophyllia inornata (Duncan) and another unidentified planula, both only discernible in vivo. Larvae of sipunculids (1 unidentified taxon), phoronids Phoronis hippocrepia Wright, Cephalochordata Branchiostoma lanceolatum (Pallas), and decapod mysis-zoeae (one unidentified taxon) were similarly recognised in vivo and a posteriori. However, distinctive colours were lost in decapod larvae after preservation. In contrast, nemertine pilidia (1 unidentified taxon) were not recognised in the samples observed a posteriori. Statistical significance for the patterns observed was not tested in these minor groups because of the small numbers of larvae in the samples. 

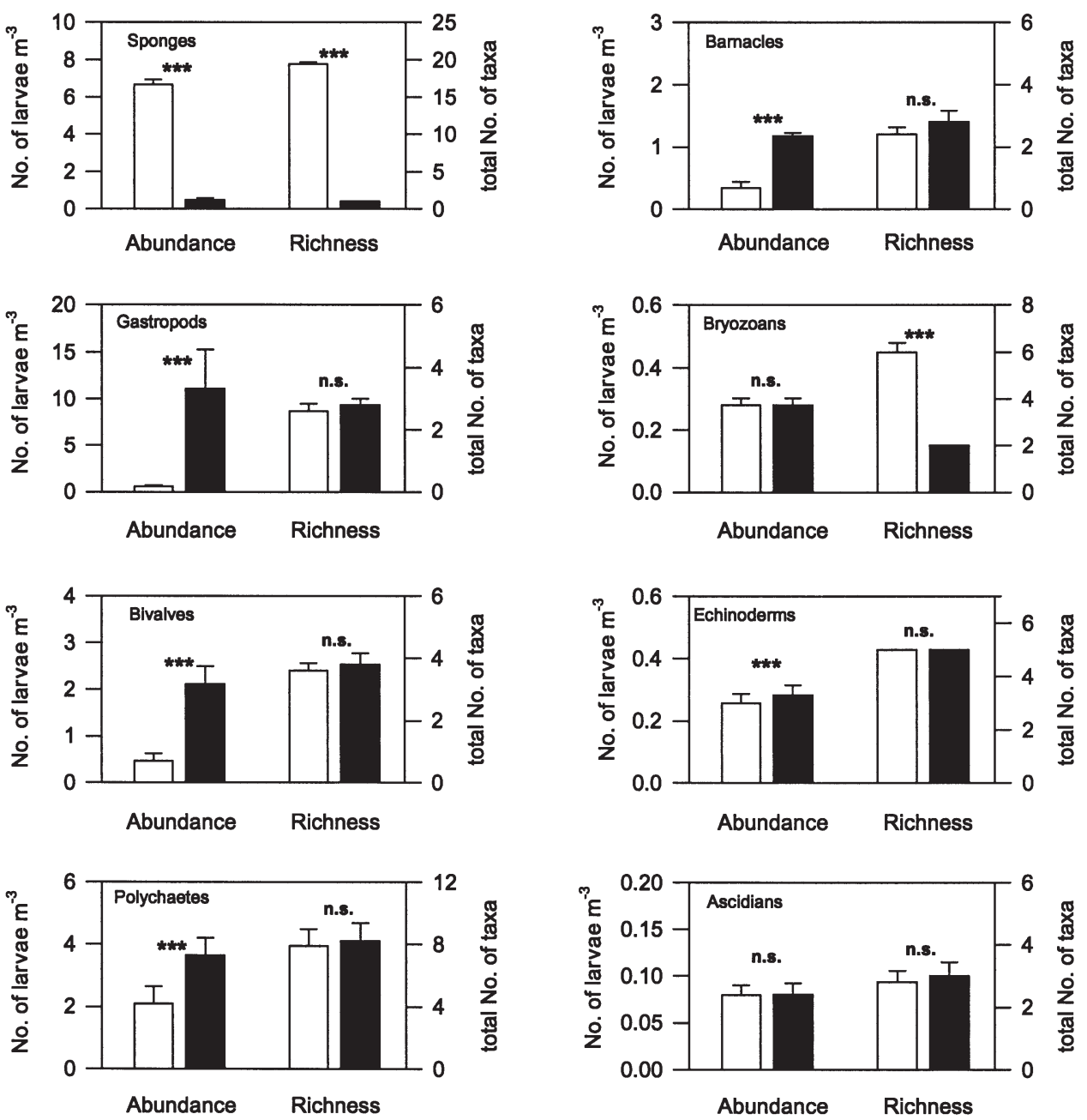

Fig. 1. Abundance and species richness of the main groups of invertebrate larvae calculated over the whole sampling period. Samples processed in vivo (white) and a posteriori (black) are shown. Histograms show mean \pm SE of the entire pool of data averaged for each of the sampling stations $(5) .{ }^{* * *} \mathrm{p}<0.001 ;$ ns: no significance; df: 1019

\section{Reef versus sandy-bottom comparisons}

Sponge larvae were significantly more abundant ( $38 \%$ of the total larvae; maximum: 100 ind. $\mathrm{m}^{-3}$ ), both as total numbers and species richness, over the reef than on the sandy bottoms off the parental habitats (13\%; Fig. 2). Some species such as Oscarella sp., Cliona viridis, Mycale rotalis, and Aplysilla sulfurea var. rosea were present only on the reef.

While gastropod veligers were significantly more abundant over the sandy bottoms $(65 \%$ of the total larvae; maximum: 1320 ind. $\mathrm{m}^{-3}$ ) than on the reef $(17 \%)$, bivalve pediveliger stages were more abundant over the reef $\left(20 \%\right.$; maximum: 110 ind. $\left.\mathrm{m}^{-3}\right)$ than on the sandy bottoms (5\%; Fig. 2). The number of taxa found did not differ significantly between substrates for either of the 2 groups (Fig. 2).
Polychaete larvae were significantly more abundant over the sandy bottoms ( $15 \%$ of the total larvae; maximum: 115 ind $\mathrm{m}^{-3}$ ), where the majority of spionid species found live (see Pinedo 1998), than on the reef $(10 \%)$, but the number of taxa did not differ significantly between substrates (Fig. 2).

Barnacle larvae were more abundant on the reef $\left(12 \%\right.$ of the total larvae; maximum: 27.2 ind $\left.\mathrm{m}^{-3}\right)$, where the adults of all the species found live, than on the sandy bottoms (1\%; Fig. 2). No significant differences in the number of taxa were observed between substrates (Fig. 2).

The smallest coronate larvae together with the few cyphonautes collected $(1.3 \%)$ were not present on the sandy bottoms. Bryozoans were significantly more abundant over the reef $(1 \%$ of the total larvae; maximum: 5.9 ind. $\mathrm{m}^{-3}$ ), as both total numbers of larvae and species 

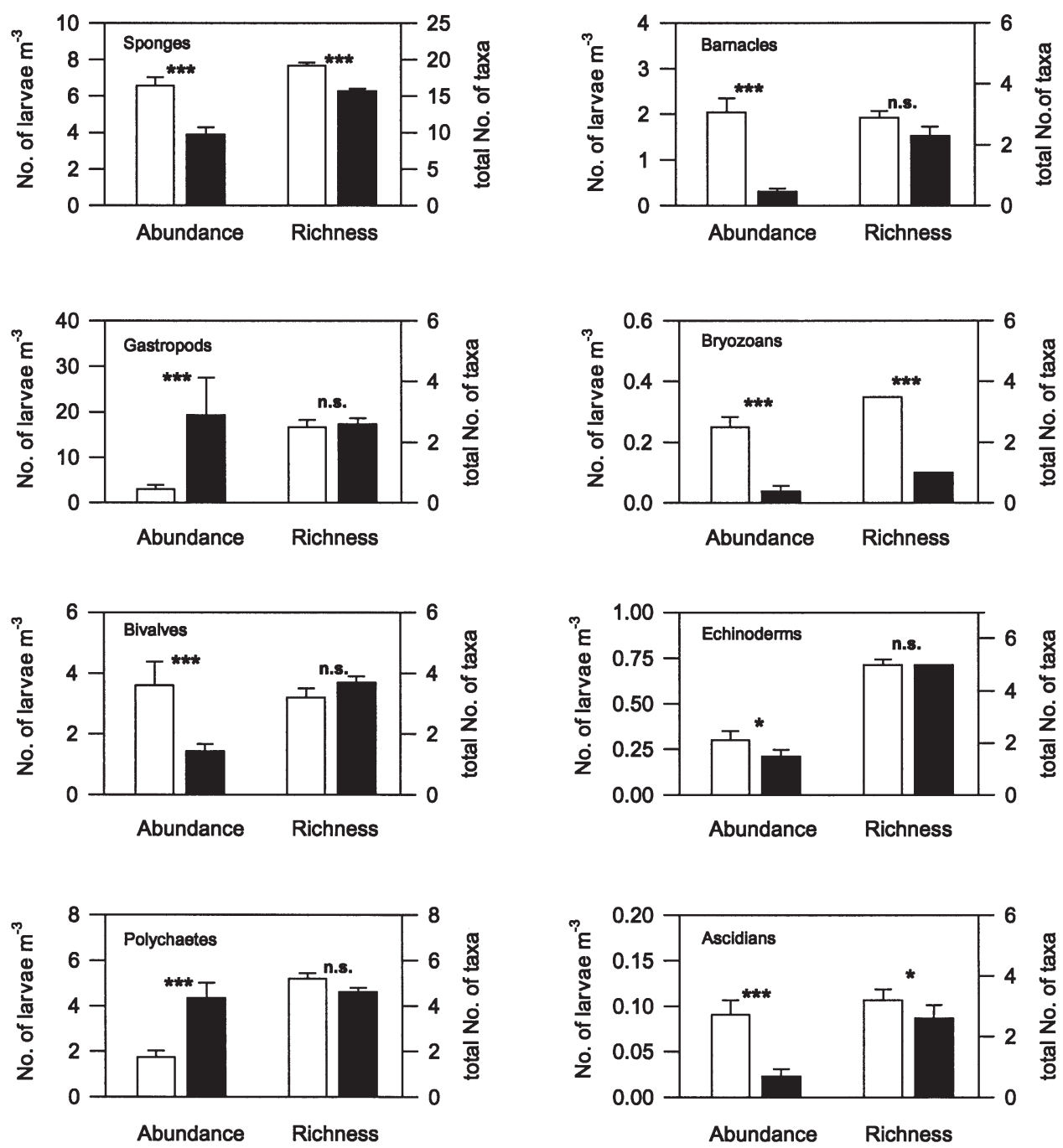

Fig. 2. Abundance and species richness of the main groups of invertebrate larvae calculated over the whole sampling period. Samples collected on the reef (white) and sandy bottoms (black) are shown. Histograms show mean \pm SE of the entire pool of data averaged for each of the sampling stations $(5) .{ }^{*} \mathrm{p}<0.05 ;{ }^{* * *} \mathrm{p}<0.001 ;$ ns: no significance; df: 509

richness, than on the sandy bottoms $(0.04 \%)$ where none of the species mentioned in Table 1 live (Fig. 2).

Overall, larvae of echinoderms were significantly more abundant over the reef $(2 \%$ of the total larvae; maximum: 21.32 ind $\mathrm{m}^{-3}$ ) than on the sandy bottoms (1\%; Fig. 2). Paracentrotus lividus colonises rocky bottoms, and juveniles of Ophiothrix fragilis are easy to find on sponges inhabiting rocky bottoms near the study area (Turon et al. 2000). No significant differences were found for the number of taxa between substrates (Fig. 2).

Significantly more ascidian larvae were collected over the reef $(1 \%$ of the total larvae; maximum: 7.35 ind. $\left.\mathrm{m}^{-3}\right)$, where the adults live, than on the sandy bottoms $(\sim 0.01 \%)$, and species richness was significantly higher on the former (Fig. 2).

\section{DISCUSSION}

The often reported general scarcity of lecithotrophic larvae in plankton depends upon several known factors such as their low numbers relative to planktotrophic larvae (Jackson 1985) and short to very short dispersal and planktonic periods (Levin \& Bridges 1995). We confirm that the distance from parental habitats at which plankton is collected is an important factor influencing the probability of collecting short-lived, short-dispersing larvae. Still, we demonstrated that methodological constraints, such as the use of formalin for preservation, can hinder abundance estimations and species identification of important meroplanktonic components, such as sponge and lecithotrophic bryozoan larvae, even though samples are collected very close to parental habitats. 
The implications of the use of formalin for the identification of adults and early stages of various marine animals have been reported in the literature (see Lincoln \& Sheals 1979, Nishikawa \& Terazaki 1996, Geldmacher \& Wieland 1999) and it is also commonly accepted (although no explicit publications exist) that formalin has detrimental effects on various invertebrate larvae. However, and in spite of such knowledge, this remains a commonly-employed method for preserving invertebrate larvae and plankton in general.

Plankton samples need to be processed in vivo prior to fixation when diagnostic characters for species identification are suspected of being lost after preservation with formalin. We must take into account that many larval stages for which species descriptions do not exist (i.e. nearly the entirety of lecithotrophic larvae) need to be cultured to postsettlement stages in the laboratory in order to be identified at the species or genus level (Rützler et al. 1980). In such cases, fixation leads directly to underestimates of species richness, since it does not allow larval culture. Indeed, in the case of sponges, not only is there a bias in the estimations of species richness, but the importance of the larvae in the plankton assemblages can also be completely overlooked. A similar situation may recur for the lecithotrophic larvae of bryozoans for which a bias in both abundance estimates, and especially taxon identification, is very likely because of sample preservation with formalin. Other short-dispersing lecithotrophic larvae, such as the ascidian tadpoles, are most often present in plankton samples collected near parental habitats and preserved with formalin after collection (Bingham 1992, Graham \& Sebens 1996), and our results confirm that neither abundance estimation nor species identification are influenced by preservation with formalin. Larval features other than colours are reliable diagnostic characters in this group (Millar 1971).

Overall, the planktotrophic larvae with hard covers (e.g. shells and carapaces) such as echinoderm pluteii, larvae of molluscs and crustaceans, and many polychaetes, showed a higher tolerance to preservation than lecithotrophic ones. Moreover, many planktotrophic larvae such as those of spionids or most veligers are fast swimmers, thus detection and counting were most easy to do once the larvae lay on the bottom of petri dishes. However, the velum features and distinctive pigmentation patterns, which are diagnostic characters for species identification in mollusc veligers and spionid larvae, respectively, were not visible once samples were preserved. Thus, even in the case of planktotrophic larvae for which detailed morphological descriptions exist, estimations of the species in the samples would greatly benefit from sample sorting in vivo prior to fixation.
It is evident that larvae of all the major groups showed a preference for either reef or sandy bottoms. Although it is difficult to determine whether such results depend on restricted dispersal, behaviour allowing larvae to return near to parental habitats, accumulation due to environmental forces, or any combination of such factors, the least likely cause appears to be accumulation due to oceanographic regimes. This is because of the particular hydrodynamics at the study site (absence of upwellings and strong currents), and proximity of the 2 substrates considered (see Mariani et al. 2000, Mariani 2002). It was an expected result of this study that the short-lived, shortdispersing larvae of sponges, bryozoans and ascidians were overall more abundant over the reef than on the sandy bottoms a few metres apart, where the adults of the collected species are absent. Moreover, possibly because of the scarcity (compared to sponges) of adults at the study site (Mariani 2002), coronate bryozoan larvae and ascidian tadpoles were rather scarce near the parental habitats, and very rare over the sandy bottoms. Short-distance dispersal (philopatry) is a common pattern within larvae of demosponges (Bergquist \& Sinclair 1968, Bergquist et al. 1970, Zea 1993), cheilostome bryozoans (Nielsen 1970, Jackson 1985, Keough 1986), and colonial didemnids (Olson 1985, Stoner 1990, 1992).

With the exception of barnacles, for which both early nauplii and cyprids were found in the samples, the majority of the other planktotrophic larvae collected (i.e. mollusc veligers, spionid larvae, and echinoderms plutei) were late developmental stages. In the case of the long-lived larvae, the initial distribution of early stages corresponds to that of the adults (Young \& Chia 1987, Pedrotti 1993). Nevertheless, although such larvae can disperse widely over the coastal shelf, late developmental stages are not uncommon near the shore where they can aggregate close to suitable habitats for settling (Graham \& Sebens 1996).

To our knowledge, this is the first long-term plankton study to have allowed a comparison of abundance and species richness between lecithotrophic larvae of sponges and bryozoans, and larvae of other benthic invertebrates. In light of our results, it appears that sponge larvae can be a primary component of meroplankton assemblages collected near the bottoms where sponges are abundant, and the importance of such meroplanktonic components needs to be further examined in future studies.

Acknowledgements. This research was supported by the European Commission (Marie Curie Fellowship to S.M. and INTAS 971-854 to M.J.U.) and the Spanish CICYT Agency (REN2001-2312). L. Dantart helped with the identification of mollusc larvae. S. Pinedo, J. Gil, D. Martin and R. Sardá 
helped with the spionids and relevant literature. N. Marbà and Ana Gordoa kindly commented on the paper. Particular thanks go to T. Alcoverro for her stimulating ideas and critical comments. This study would not have been possible without boat assistance provided by I. Abreu and G. Carreras.

\section{LITERATURE CITED}

Amano S (1988) Morning release of larvae controlled by the light in an intertidal sponge, Callyspongia ramosa. Biol Bull 175:181-184

Andreu P, Duarte CM (1996) Zooplankton seasonality in the Blanes Bay (northwestern Mediterranean). Publ Espec Inst Esp Oceanogr 22:47-54

Bergquist PR, Sinclair ME (1968) The morphology and behaviour of larvae of some intertidal sponges. NZ J Mar Freshw Res 2:426-437

Bergquist PR, Sinclair ME, Hogg JJ (1970) Adaptation to intertidal existence: reproductive cycles and larval behaviour in Demospongiae. Symp Zool Soc Lond 25:247-271

Bingham BL (1992) Life histories in an epifaunal community: coupling of adult and larval processes. Ecology 73: 2244-2259

Emery AR (1968) Preliminary observations on coral reef plankton. Limnol Oceanogr 13:293-303

Geldmacher A, Wieland K (1999) Implications of mechanical deformation and formaldehyde preservation for the identification of stage-specific characteristics of Baltic cod eggs. J Appl Ichthyol 15:75-79

Graham KR, Sebens KP (1996) The distribution of marine invertebrate larvae near vertical surfaces in the rocky subtidal zone. Ecology 77:933-949

Hurlbut CJ (1991) The race is not always to the swift: benthic predation on ascidian and sponge larvae. Am Zool 31:7A

Jackson JBC (1985) Distribution and ecology of clonal and aclonal benthic invertebrates. In: Jackson JBC, Buss LW, Cook E (eds) Population biology and evolution of clonal organisms. Yale University Press, New Haven, p 297-356

Jackson JBC (1986) Modes of dispersal of clonal benthic invertebrates: consequences for species' distributions and genetic structure of local populations. Bull Mar Sci 39: 588-606

Keough MJ (1986) The distribution of a bryozoan on seagrass blades: settlement, growth and mortality. Ecology 67: 846-857

Keough MJ (1989) Dispersal of the bryozoan Bugula neritina and effects of adults on newly metamorphosed juveniles. Mar Ecol Prog Ser 57:163-171

Levin LA, Bridges TS (1995) Pattern and diversity in reproduction and development. In: McEdward L (ed) Ecology of marine invertebrate larvae. CRC Press, Boca Raton, FL, p 79-122

Lincoln RJ, Sheals JG (1979) Invertebrate animals. Collection \& preservation. British Museum (Natural History), London

Lindquist N, Hay ME (1996) Palatability and chemical defence of marine invertebrate larvae. Ecol Monogr 62: $547-568$

Lindquist N, Bolser RC, Laing K (1997) Timing of larval release by two Caribbean demosponges. Mar Ecol Prog Ser 155:309-316

Mariani S (2002) Larval supply and recruitment of invertebrates in the western Mediterranean: patterns in contrasting benthic communities. PhD thesis, University of Barcelona

Mariani S, Uriz MJ, Turon X (2000) Larval bloom of the oviparous sponge Cliona viridis: coupling of larval abundance and adult distribution. Mar Biol 137:783-790
Martin D, Claret M, Pinedo S, Sardá R (1997) Vertical and spatial distribution of the near-shore littoral meroplankton off the Bay of Blanes (NW Mediterranean Sea). J Plankton Res 19:2079-2089

Mileikovsky SA (1968a) Some common features in the drift of pelagic larvae and juvenile stages of bottom invertebrates with marine currents in temperate regions. Sarsia 34: 209-216

Mileikovsky SA (1968b) Distribution of pelagic larvae of bottom invertebrates of the Norwegian and Barents Seas. Mar Biol 1:161-167

Millar RH (1971) The biology of ascidians. Adv Mar Biol 9: $1-100$

Nielsen C (1970) On metamorphosis and ancestrula formation in cyclostomatous bryozoans. Ophelia 7:217-256

Nishikawa J, Terazaki M (1996) Tissue shrinkage of two gelatinous zooplankton, Thalia democratica and Dolioletta gegenbauri (Tunicata:Thaliacea) in preservative. Bull Plankton Soc Jpn 43:1-7

Olson RR (1985) The consequences of short-distance larval dispersal in a sessile marine invertebrate. Ecology 66:30-39

Palau M, Cornet C, Riera T, Zabala M (1991) Planktonic gradients along Mediterranean sea cave. Oecol Aquat 10: 299-316

Pedrotti ML (1993) Spatial and temporal distribution and recruitment of echinoderm larvae in the Ligurian Sea. J Mar Biol Assoc UK 73:513-530

Pinedo S (1998) Structure and dynamics of Western Mediterranean soft-bottom communities along a disturbance gradient. Natural and man-induced variability in the Bay of Blanes. PhD thesis, University of Barcelona

Rützler K, Ferraris JD, Larson RJ (1980) A new plankton sampler for coral reefs. PSZN I: Mar Ecol 1:65-71

Ryland J S (1976) Behaviour, settlement and metamorphosis of bryozoan larvae: a review. Thalassia Jugosl 10:239-262

Sale PF, McWilliam PS, Anderson DT (1976) Composition of near-reef zooplankton at Heron Reef, Great Barrier Reef. Mar Biol 34:59-66

Sale PF, McWilliam PS, Anderson DT (1978) Faunal relationship among the near-reef zooplankton at three locations on Heron Reef, Great Barrier Reef. Mar Biol 49:133-145

Sautor B, Castel J (1995) Comparative spring distribution of zooplankton in three macrotidal European estuaries. Hydrobiologia:139-151

Scheltema RS (1971) The dispersal of the larvae of shoalwater benthic invertebrate species over long distances by ocean currents. In: Crisp DJ (ed) Proc 4th Eur Mar Biol Symp. Cambridge University Press, Cambridge, p 7-28

Scheltema RS (1986) Long distance dispersal by planktonic larvae of shoal-water benthic invertebrates among central Pacific Islands. Bull Mar Sci 39:241-256

Scheltema RS, Williams IP (1983) Long distance dispersal of planktonic larvae and the biogeography and evolution of some Polynesian and Western Pacific mollusks. Bull Mar Sci 33:545-565

Southward AJ (1962) The distribution of some plankton animals in the English Channel and approaches II. Survey with the Gulf III high-speed sampler, 1958-60. J Mar Biol Assoc UK 42:275-375

Stoner DS (1990) Recruitment of a tropical colonial ascidian: relative importance of pre-settlement vs. post-settlement processes. Ecology 71:1682-1690

Stoner DS (1992) Vertical distribution of a colonial ascidian on a coral reef: the roles of larval dispersal and life-history variation. Am Nat 139:802-824

Svane I, Young CM (1989) The ecology and behaviour of ascidian larvae. Oceanogr Mar Biol Annu Rev 27:45-90 
Trégouboff G (1939) La Station Zoologique de Villefranchesur-Mer. I. Son histoire. II. Sa reison d'être. Comptes Rendus de l'Acadèmie des Sciences, Paris, p 302-309

Uriz MJ, Maldonado M, Turon X, Martí R (1998) How do reproductive output, larval behaviour, and recruitment contribute to adult spatial patterns in Mediterranean encrusting sponges? Mar Ecol Prog Ser 167:137-148

Valdes JL, Roman MR, Alvarez-Ossorio MT, Gauzens AL, Miranda A (1990) Zooplankton composition and distribution off the coast of Galicia, Spain. J Plankton Res 12: $629-643$

Vives F (1966) Zooplankton nerítico de las aguas de Castellón (Mediterráneo occidental). Invest Pesq 30:49-166

Editorial responsibility: Otto Kinne (Editor),

Oldendorf/Luhe, Germany
Wang Z, Dauvin JC, Thiebaut E (1994) Preliminary data on the near-bottom meso- and macrozooplanktonic fauna from the eastern Bay of Seine: faunistic composition, vertical distribution and density variation. Cah Biol Mar 35: $157-176$

Young CM, Chia FS (1987) Abundance and distribution of pelagic larvae as influenced by predation, behavior, and hydrogeographic factors. In: Giese AC (ed) Reproduction of marine invertebrates, Vol 9. Blackwell Scientific Publications, Palo Alto, p 385-464

Zea S (1993) Recruitment of Demosponges (Porifera, Demospongiae) in rocky and coral reef habitats of Santa Marta, Colombian Caribbean. PSZN I: Mar Ecol 14:1-21

Submitted: July 15, 2002; Accepted: February 14, 2003 Proofs received from author(s): April 22, 2003 